\title{
Öğretmen Eğitimi Programlarını Değerlendirme Ölçeğinin Geçerlik ve Güvenirlik Çalışması (ÖEPDÖ)
}

\author{
Arș. Gör. Muhammed Akınci ${ }^{1^{*}}$ \\ Prof. Dr. Erdoğan Köse ${ }^{2}$
}

Geliş tarihi: 02.03.2019

Kabul tarihi: 20.03.2019

\section{Atıf bilgisi:}

Uluslararası Bilimsel

Araștırmalar Dergisi (IBAD)

Cilt: $4 \quad$ Sayı: 2

Sayfa: 236-252 Yll: 2019

Dönem: Yaz

This article was checked by Turnitin. Similarity Index 16\%

${ }^{1}$ Recep Tayyip Erdoğan Üniversitesi, Türkiye,

muhammed.akinci@erdogan.edu.tr, ORCID ID 0000-0002-5001-2080

${ }^{2}$ Akdeniz Üniversitesi, Türkiye, ekose@akdeniz.edu.tr,

ORCID ID 0000-0003-0426-0267

* Sorumlu yazar

\begin{abstract}
ÖZ
$\mathrm{Bu}$ araştırmanın amacı eğitim fakültesi lisans programlarının öğretmen adaylarının bakış açıları ile değerlendirilmesine olanak tanıyacak bir ölçeğin geliştirilmesidir. Bu çalışmada başta Sistem/Karar Odaklı Program Değerlendirme Yaklaşımı olmak üzere Türkiye'de ve dünyada yaygın olarak kullanılan çeşitli program değerlendirme yaklaşım ve modellerinin yapısal özellikleri göz önünde bulundurularak hazırlanan Öğretmen Eğitimi Programlarını Değerlendirme Ölçeği (ÖEPDÖ)'nin geçerlik ve güvenirlik çalışması yapılmıştır. Bu bağlamda araştırma verileri gönüllülük esasına bağlı olarak Akdeniz Üniversitesi Eğitim Fakültesi 3. ve 4. sınıflarda öğrenim gören 363 öğretmen adayından toplanmıştır. Hazırlanan ölçeğin yap1 geçerliğini belirlemek için Açımlayıcı Faktör Analizinden faydalanılmıştır. Ölçeğin güvenirliğini tespit etmek için ise "Cronbach's Alpha", "Spearman-Brown İki Yarı Test Güvenirliği” puanları hesaplanmıştır. Ayrıca "Madde Toplam Puan Korelasyonları" ve alt \%27 ve üst \%27'lik grupların puanları arasındaki "İlişkisiz Örneklemler için t Testi" sonuçları incelenmiştir. Ölçeğin tüm faktörleri için Cronbach's Alpha ve Spearman Brown güvenirlik katsayıları .75 ile .79 arasındadır. Ayrıca ölçeğe dâhil edilen maddelerin madde toplam korelasyonları .31 ile .68 arasında değişmektedir. Ayrıca alt \%27 ve üst \%27'lik grupların ortalama puanları arasındaki fark anlamlıdır $(\mathrm{p}<.001)$. Yapılan bu analizler sonucunda 13 ' $\mathrm{u}$ olumsuz madde olmak üzere 47 maddeden oluşan taslak toplam varyansın $\% 43,2$ 'sini açıklayan 5 faktörlü, 30 maddelik, 5'li likert tipi geçerli ve güvenilir bir ölçek haline gelmiştir.
\end{abstract}

Anahtar Kelimeler: Program değerlendirme, ölçek geliştirme, öğretmen eğitimi. 


\title{
Validity and Reliability Study of Teacher Training Curriculum Evaluation Scale (TTCES)
}

\author{
Res. Asst. Muhammed Akıncı ${ }^{1^{*}}$ \\ Prof. Dr. Erdoğan Köse ${ }^{2}$
}

First received: 02.03.2019

Accepted: 20.03.2019

\section{Citation:}

Journal of the International Scientific Research (IBAD)

Volume: 4 Issue: 2

Pages: 236-252 Year: 2019

Session: Summer

This article was checked by Turnitin. Similarity Index 16\%

${ }^{1}$ Recep Tayyip Erdoğan University, Turkey,

muhammed.akinci@erdogan.edu.tr. ORCID ID 0000-0002-5001-2080

${ }^{2}$ Akdeniz University, Turkey,

ekose@akdeniz.edu.tr,

ORCID ID 0000-0003-0426-0267

* Corresponding Author

\begin{abstract}
The aim of this study is to develop a scale that will enable the evaluation of faculty of education teacher training programs with the perspectives of teacher candidates. In this research, the validity and reliability study of Teacher Training Curriculum Evaluation Scale (TTCES) was conducted which was prepared by considering the structural features of various curriculum evaluation approaches and models widely used in Turkey and in the World. The research data was collected from 363 volunteer teacher candidates from $3^{\text {rd }}$ and $4^{\text {th }}$ grades who study in Akdeniz University Faculty of Education. Exploratory Factor Analysis was used to determine the construct validity of the prepared scale. In order to determine the reliability of the scale, 'Cronbach's Alpha" and 'Spearman-Brown" test scores were calculated. Moreover, Item Total Correlation scores and the results of Independent Samples T Test between the lower $27 \%$ and the upper $27 \%$ groups were examined for reliability. Cronbach's Alpha and Spearman Brown reliability coefficients for all factors were between .75 and .79 . and total correlations of the items included in the scale range from .31 to .68 . Moreover, the difference between mean scores of the lower $27 \%$ and the upper $27 \%$ groups was significant $(p<.001)$. After these analyzes, the draft consisting of 47 items, became a valid and reliable 5-point Likert type scale with 5 factors and 30 -items explaining $43.2 \%$ of the total variance.
\end{abstract}

Keywords: Curriculum evaluation, scale development, teacher training. 


\section{INTRODUCTION}

Curriculum development and evaluation are dynamic and cyclic processes. Definitions of the curriculum development and evaluation concepts state this situation more clearly. Yüksel \& Sağlam (2014) state that curriculum development is the design, implementation, evaluation and reorganization of the curriculum while curriculum evaluation is to evaluate designed and implemented curriculum in accordance with scientific research processes and appropriate curriculum evaluation models and to use these results in the development of the curriculum. Uşun (2012) also states that curriculum development is making basic elements of the curriculum valid, useful, efficient and effective in the light of various developments and scientific research processes and curriculum evaluation is the process of deciding whether the developed curriculum has the qualifications mentioned by using the same scientific research activities and making decision about any feature of the curriculum.

When the literature related to curriculum evaluation is examined, it is possible to see some classifications based on various approaches and models. Some of the most common ones and their representatives are as follows (Fitzpatrick, et al., 2011; Yüksel \& Sağlam, 2014; Uşun, 2012; Demirtaş, 2017; Aygören \& Er, 2018):

- Objective/Program-Oriented Evaluation Approaches

$\circ$ The Tylerian Evaluation Approach

- Metfessel-Michael Evaluation Model

- Provus's Discrepancy Evaluation Model

- Expertise Oriented Approach

- Eisner's Educational Connoisseurship and Criticism Models

- Consumer-Oriented Approach

- Participant-Oriented Evaluation Approaches

○ Robert Stake's Responsive Approach

- Stake's Congruence-Contingency Model

- System/Decision-Oriented Approach

- Stufflebeam's CIPP Model: Context, Input, Process, and Product.

- The UCLA Evaluation Model.

\section{Objective/Program-Oriented Evaluation Approaches}

Objective/Program-Oriented Evaluation Approaches focus on the extent to which those objectives, are achieved after the teaching and learning activities. In these approaches, the main role of the curriculum evaluator is to decide how much and how well the curriculum objectives have been achieved (Fitzpatrick, et al., 2011). When the objectives of the curriculum are clearly expressed these approaches are considered as successful in providing the decision-makers with useful information because in this situation the implementation stages are evident too. However, only focusing on the objectives is criticized in this aspect because it is considered to be a risk of neglecting the curriculum characteristics that are not mentioned in the objectives (Stufflebeam, et al., 2006; Fitzpatrick, et al., 2011).

\section{Expertise Oriented Approach}

In contrast to previous approaches, Expertise Oriented Approach is seen as a post-modern and humanist approach because its basic focus in the evaluation of curriculum is not to train individuals who will contribute to the economic system (Ornstein \& Hunkins 2018). This approach focuses on the field of expertise in curriculum evaluation (Yüksel \& Sağlam, 2014; Uşun, 2012).

Although Expertise Oriented Approach is considered to be important as a humanistic approach and academic freedom environment it presents, it is criticized because of the difficulty of expert choice in terms of proficiency and objectivity (Fitzpatrick, et al., 2011).

\section{Consumer-Oriented Approach}

Consumer-oriented assessments first became important in the evaluation of educational products from the mid-1960s to the end. The most important reason for this situation is that the US governments began to offer serious funds to develop new educational products (Fitzpatrick, et al., 2011). 
The pioneer representative of this approach is seen as Michael Scriven. In general, Scriven's approach in evaluation, aims at determining and grading the costs and impacts of alternative programs and educational products that consumers and broader society can use according to the assessed needs, and in doing so uses product evaluation checklists (Stufflebeam \& Coryn 2014).

The Consumer-oriented Approach is seen as successful in raising awareness about the quality of educational products and providing some standards for the curriculum (Stufflebeam, et al., 2000). In addition, high costs and sometimes unnecessary rules are seen as weaknesses of the approach (Fitzpatrick, et al., 2011).

\section{Participant-Oriented Evaluation Approaches}

The emergence of the Participatory-Oriented Evaluation Approaches are based on the reaction that in the first years of curriculum evaluation in the United States the fundamental characteristics of evaluation are limited with the extent how much the objectives or standards have been achieved. Towards the end of the 1960s, including Robert E. Stake, some educators stated that curriculum evaluation processes were nothing more than comprehensive reports written after long mechanical studies as a result of which actually the curriculum evaluators were not able to fully control the curriculum they evaluate. These scientists argued that during the evaluation process the participant element of the curriculum should be given more attention, so that the curriculum can be evaluated more effectively with different perspectives (Stake, 1967; Fitzpatrick, et al., 2011; Yüksel \& Sağlam, 2014).

The Participatory-Oriented Evaluation Approaches are widely preferred approaches because they emphasize the human factor and allow for a variety of subjective, objective, qualitative and quantitative data collection processes. However, these approaches are criticized for the high costs, difficulty of analyzing many different types of data and providing validity, reliability and objectivity (Fitzpatrick, et al., 2011; Yüksel \& Sağlam, 2014).

\section{System/Decision-Oriented Approach}

At the end of the 1960s, System/Decision-Oriented Approach became an alternative to Objective Oriented Approaches and models. In this respect, this approach is focused on the decisions of the managers rather than the objectives of the curriculum. While this approach is seen as systematic and planned in different aspects of the curriculum, it is criticized that the manager-oriented perspective sometimes causes subjective evaluations (Fitzpatrick, et al., 2011; Yüksel \& Sağlam, 2014).

When the studies carried out in Turkey to develop curriculum evaluation scales were examined it is possible to see some scales that they are not based on any curriculum evaluation approach and model, benefiting from the overall curriculum evaluation approaches or a large number of studies using Stufflebeam's CIPP Evaluation Model (Budak, 2011; Öksüz, 2015; Baş, 2016; Aslan, Soyalp, Karahan \& Altuntaş, 2016; Akdoğdu \& Uşun, 2017; Kavgaoğlu, 2017). This case is an indication of the effectiveness of the System/Decision-Oriented Approach in the structure and content features of the developed curriculum evaluation scales in Turkey. Of course, this approach does not only consist of CIPP Evaluation Model. However, considering the prevalence of usage, it is an undeniable truth that one of the most common models under this approach is CIPP Evaluation Model. In addition, different sources of information providing information about the System/Decision Oriented Approach also mention about the UCLA Evaluation Model, which is a common model under these approaches (Fitzpatrick, et al., 2011; Yüksel \& Sağlam, 2014; Uşun, 2012). For this reason, it is possible to say that System/Decision Oriented Approach, Stufflebeam's CIPP Evaluation Model and UCLA Evaluation Model have a weighted effect compared to other approaches and models while preparing Teacher Training Curriculum Evaluation Scale (TTCES).

Stufflebeam's CIPP Evaluation Model, which can be called as the most important example of the System/Decision-Oriented Approach, aims to gather information and make decisions about the curriculum (Ornstein \& Hunkins, 2018). This model was developed in the late 1960s to improve the education quality and provide controllability of federal public schools in the US. (Stufflebeam \& Coryn, 2014). In CIPP Evaluation Model, the curriculum is evaluated in 4 dimensions as Context, Input, Process and Product (Kellaghan \& Stufflebeam, 2003). These dimensions are likened to the evaluation 
dimensions of the UCLA Evaluation Model (Fitzpatrick, et al., 2011). Alkin \& Woolley (1969) state these dimensions as:

- Systems assessment,

- Program planning,

- Program implementation,

- Program improvement and

- Program certification.

The Evaluation of the Process in UCLA Evaluation Model is discussed in two dimensions: Program Implementation and Program improvement. However, all dimensions except the Process are similar to the dimensions Context, Input and Product of CIPP Evaluation Model.

\section{PURPOSE OF THE STUDY}

The aim of this study is to develop a scale that will enable the evaluation of faculty of education teacher training programs with the perspectives of teacher candidates. The developed scale is expected to be beneficial for including the students in evaluation processes with their beliefs towards program competencies who are among the most important inputs of the curriculum. Especially, the inclusion of adult individuals studying in undergraduate programs into evaluation processes is important because this participation can be a tool that will facilitate the multiplication of data for researchers who conduct curriculum evaluation studies.

\section{METHOD}

In this research, the validity and reliability study of Teacher Training Curriculum Evaluation Scale (TTCES) was carried out which was prepared by considering the structural features of various curriculum evaluation approaches, especially System/Decision Oriented Approach and Models widely used in Turkey and in the World.

\section{Study Group}

The study group is composed of the $3^{\text {rd }}$ and $4^{\text {th }}$ grades students who study in Akdeniz University Faculty of Education. In this context, research data was collected from 363 volunteer teacher candidates to conduct the validity and reliability studies of the scale.

\section{Data Analysis}

IBM SPSS Statistics 25 application was used for data analysis. While the data was entered into the application, 19 were not included in the data set due to missing information. In addition, "Crosstabs" and "Boxplot" techniques were used for scanning outliers before data analysis. Thus, 27 outlier data were extracted from the data set. After all of these operations, 317 data were used for validity and reliability analyzes. Of these data, $73.2 \%$ belong to female, $26.8 \%$ male teacher candidates, and $65.6 \%$ of these students' study in the $3^{\text {rd }}$ grade and $34.4 \%$ in the $4^{\text {th }}$ grade. Moreover, the distribution of the participants according to the faculty of education departments is presented in Table 1:

Table 1. Distribution of The Data According Departments

\begin{tabular}{lcc}
\hline \multicolumn{1}{c}{ Faculty of Education Departments } & Distribution of The Data & Distribution Percent \\
\hline Elementary Education & 42 & 13,2 \\
Early Childhood Education (Formal Education) & 30 & 9,5 \\
Early Childhood Education (Evening Education) & 32 & 10,1 \\
Mathematics Education & 35 & 11,0 \\
Science Education & 86 & 27,1 \\
Turkish Education & 28 & 8,8 \\
Social Sciences Education & 17 & 5,4 \\
Psychological Counseling and Guidance & 15 & 4,7 \\
English Language Teaching & 32 & 10,1 \\
\hline Total & $\mathbf{3 1 7}$ & $\mathbf{1 0 0 , 0}$ \\
\hline
\end{tabular}


When the Table 1 is examined, it can be seen that the student distributions are proportionally divided according to the department, class and gender variables. There are several reasons for these divergences. First of all, the participation of the students from each department in the scale development study differed in terms of volunteering. In addition, the density of applied courses of $4^{\text {th }}$ grade students caused difficulty to reach these individuals and the number of female teacher candidates was higher in the faculty where the scale was developed. All these cases can be expressed as the limitations of the study.

The validity and reliability studies of the scale were carried out by using the data collected from the teacher candidates whose demographic information was given above. Exploratory Factor Analysis was used to determine the construct validity of the prepared scale. In order to determine the reliability of the scale, 'Cronbach's Alpha" and 'Spearman-Brown" test scores were calculated. Moreover, Item Total Correlation scores and the results of Independent Samples t Test between the lower 27\% and the upper $27 \%$ scores were examined for reliability. It is stated in different sources that these stages and analyzes should be applied in scale development processes (Dimitrov, 2012; Tabachnick \& Fidell, 2013; Garson, 2013).

\section{Preparation of The Scale}

It could be said that the process of preparation of the scale took place in three stages.

\section{Examination of theoretical foundations}

In the study before moving on to the item writing, basic curriculum evaluation approaches and models, primarily System/Decision-Oriented Approach and models, were examined from various curriculum evaluation sources (Stake, 1967; Metfessel \& Michael, 1967; Provus, 1969; Eisner, 2002; Kellaghan \& Stufflebeam 2003; Stufflebeam, et al., 2006; Fitzpatrick, et al., 2011; Uşun, 2012; Stufflebeam \& Coryn 2014; Yüksel \& Sağlam, 2014; Patton, 2015; Ornstein \& Hunkins 2018).

\section{Review of contextual literature on scale development}

In the next process, a variety of curriculum evaluation scales developed in Turkey were examined. In addition, a total of 130 researches including 34 articles, 59 master's thesis and 37 doctoral theses on curriculum evaluation have been reached which were carried out in the last 10 years in Turkey. From these studies, 33 studies that used a curriculum evaluation approach and model have been examined. As a result of these analyzes, a 40-items scale draft with 5-point Likert type was created by taking the objective, content, education and evaluation elements into consideration which are the main elements of the curriculum and the context, input, process and product dimensions commonly used in curriculum evaluation processes.

\section{Expert opinions and final corrections}

About the prepared scale draft 3 curriculum development experts' and 2 measurement, evaluation and statistic experts' opinions were received. In line with the recommendations of these experts, some items were removed from the draft, some were corrected, and some new items were included in the draft. As a result, the draft became ready for application consisting of 47 items, 13 of which are negative items. The options of the prepared scale draft were arranged from 1 to 5 as "Strongly Disagree", "Disagree", "Undecided" "Agree", "Strongly Agree".

\section{FINDINGS AND COMMENTS}

\section{Findings and Comments Towards Validity of the Scale}

Kaiser-Meyer-Olkin (KMO) and Bartlett Sphericity tests were examined before exploratory factor analysis. The Kaiser-Meyer-Olkin (KMO) test result was found .82 . This value above .60 indicates that the data is suitable for factor analysis (Büyüköztürk, 2014). Bartlett Sphericity Test was significant $(\chi 2=$ 2301,$86 ; \mathrm{p}=.000$ ). This result again suggests that the data is suitable for factor analysis (Tabachnick \& Fidell, 2013).

Before deciding whether to use orthogonal or oblique rotation during factor analysis, it was assumed that there might be a relationship among factors since the research was conducted in the field of social sciences. In order to see whether this assumption was met statistically, one of the oblique rotation 
methods "Promax" was used at first. If it is thought that there is a relationship among factors oblique rotation is preferred (Çokluk, et al., 2016). After oblique rotation .55 correlation between the $1^{\text {st }}$ and $2^{\text {nd }}$ factors and .36 correlation between $1^{\text {st }}$ and $3^{\text {rd }}$ factors were found. This shows that the oblique rotation method is an appropriate choice during exploratory factor analysis. Tabachnick \& Fidell (2013) stated that when deciding on the rotation method, most appropriate way is to make oblique rotation with the desired number of factors and to look at the correlations between them, and to choose oblique rotation if the correlations exceeded .32 .

There are several ways to decide on the number of factors in the scale development process. One of the most commonly used methods is to look at the eigenvalues of the components. From these components, we can accept each as a factor with eigenvalues greater than 1.0 (Thompson, 2004; Çokluk, et al., 2016). Another method is the graphic test called "Scree Test". In this test, the components with higher than 1.0 eigenvalues are included in the scale from the point of the beginning of the noticeable uplift in the graph (Thompson, 2004).

Figure 1. Scree Test Graphic

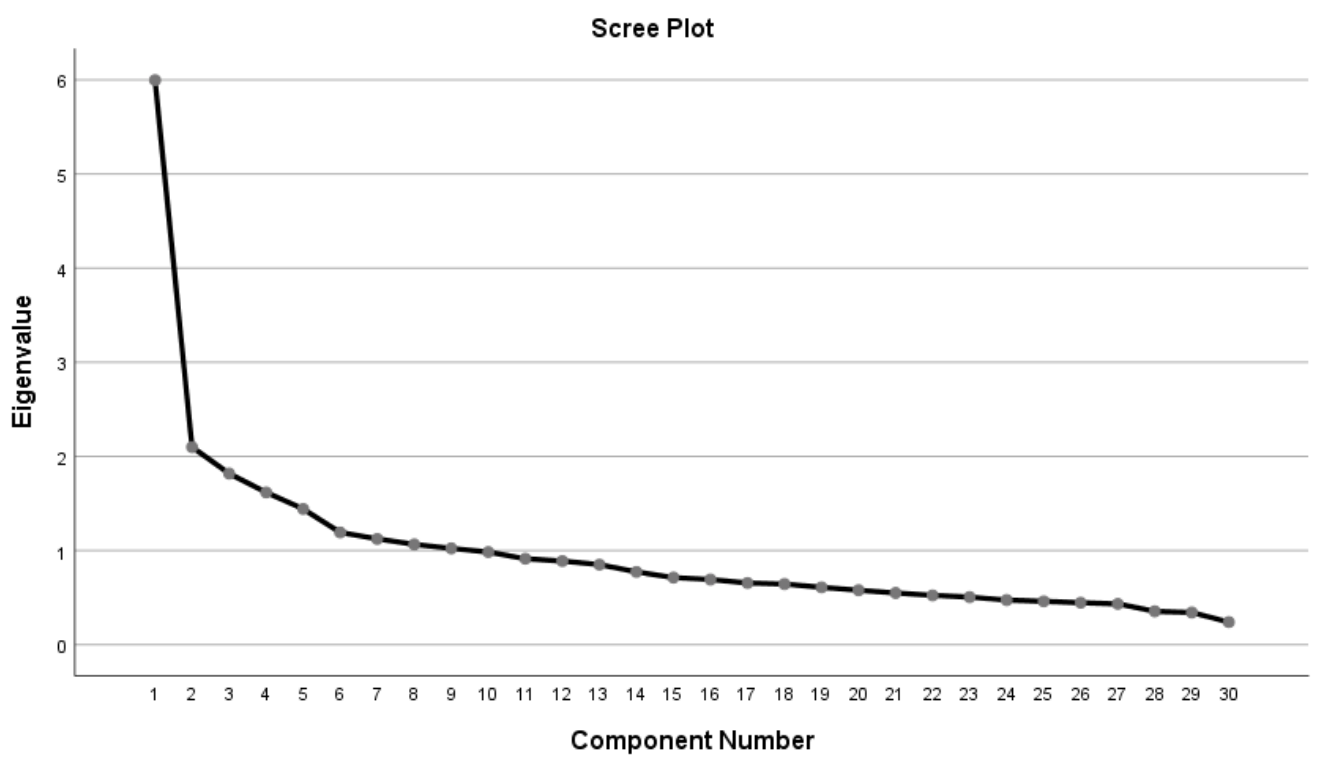

After examining the eigenvalues of the components in the exploratory factor analysis and the Scree test, it was observed that 7 dimensions of the factorization took place. However, considering the theoretical foundations of the scale, a scale of 4 or 5 factors was planned. Moreover, the statistics application did not provide "pattern matrix" graphic for more than 5 factors for the scale. and the noticeable uplift in the graph was observed for 5 factors. For this reason, 5 factors are included in the scale corresponding with the theoretical foundations. Factor load values were taken into consideration when deciding the items to be included in the scale. Regardless of whether it is negative or positive, the load value above 60 is considered as high and, the load value between .30 and .59 is acceptable and can be included in the scale (Büyüköztürk, 2002). In this context, the items with factor loadings greater than .30 are included in the scale. Moreover, of the items included in the scale, 9 items with negative values were recoded. Factor load values resulting from this process and distribution of items by factors are shown in Table 2:

Table 2. Factor Load Values and Distribution of Items by Factors

\begin{tabular}{c|ccccc}
\hline \multirow{2}{*}{ Item } & \multicolumn{4}{|c}{ Factor Load Values } \\
\cline { 2 - 5 } Numbers & F1 & F2 & F3 & F4 & F5 \\
\hline $\mathbf{2 5 .}$ &, 755 & & & & \\
$\mathbf{1 9 .}$ &, 749 & & & & \\
$\mathbf{1 3 .}$ &, 732 & & & & \\
$\mathbf{1 4 .}$ &, 693 & & & & \\
$\mathbf{3 2 .}$ &, 631 & & & &
\end{tabular}




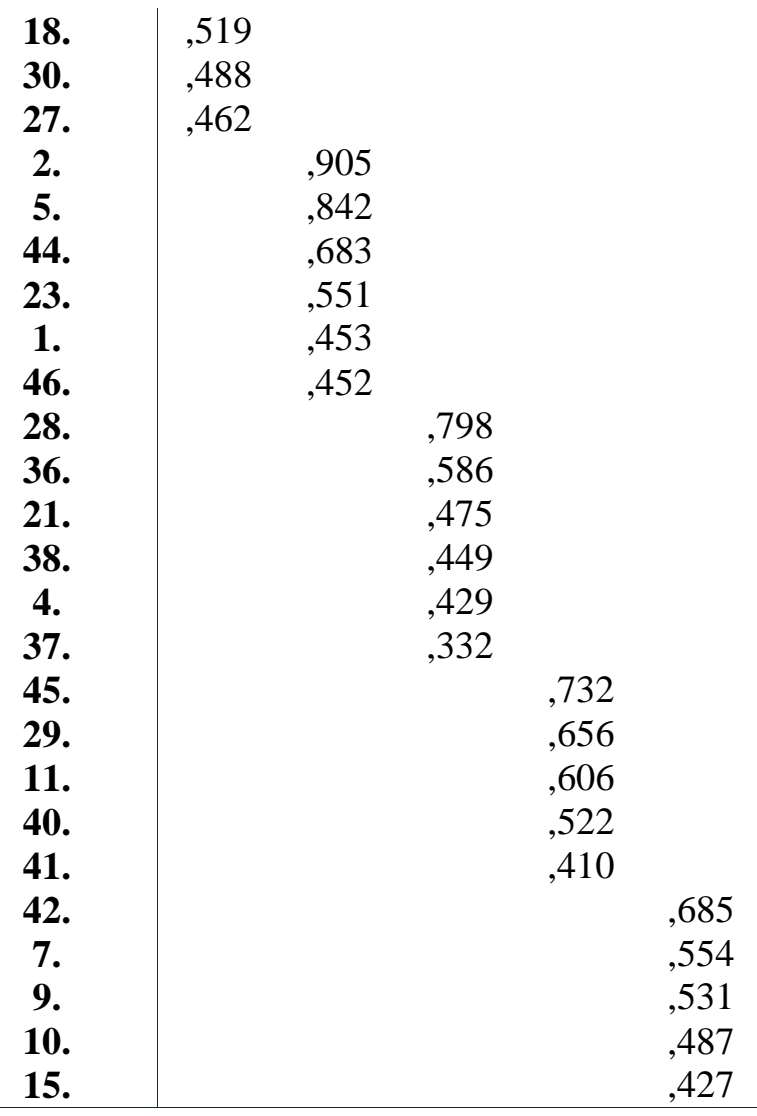

When Table 2: results of the exploratory factor analysis are examined, it can be seen that a scale with 30 items ranging from .90 to .33 load values has emerged. In addition, there are 8 items in the 1 th factor, 6 items in 2nd and 3rd factors, and 5 items in 4th and 5 th factors. The eigenvalues of the scale factors and their variance ratios are given in Table 3:

Table 3. Factor Eigenvalues and Explained Variance Ratios

\begin{tabular}{cccc}
\hline Factors & Factor Eigenvalues & Explained Variance Ratios & Total Variance Explained \\
\hline F1 & 5,996 & 19,988 & 19,988 \\
F2 & 2,099 & 6,995 & 26,983 \\
F3 & 1,818 & 6,058 & 33,041 \\
F4 & 1,617 & 5,392 & 38,433 \\
F5 & 1,442 & 4,805 & 43,238 \\
\hline
\end{tabular}

When Table 3 is examined, it can be said that a scale has emerged with 30 items consisting 5 factors with eigenvalues above 1.0 which explain $43.2 \%$ of the total variance. It is difficult to keep the ratio of variance explained high in social sciences (Büyüköztürk, 2002). For this reason, in multi-factor scales, $40 \%$ to $60 \%$ of the total variance is in the acceptable range (Büyüköztürk, 2014; Çokluk, et al., 2016).

Findings and Comments Towards Reliability of the Scale

After completion of the exploratory factor analysis, construct validity was ensured to begin reliability analysis of the scale. In this context, the data about the reliability of the scale is presented in Table 4 and Table 5:

Table 4. Cronbach's Alpha and Spearman-Brown Reliability Coefficients

\begin{tabular}{cccc}
\hline Factors & $\begin{array}{c}\text { Cronbach's Alpha } \\
\text { Reliability Coefficients }\end{array}$ & $\begin{array}{c}\text { Spearman-Brown } \\
\text { Reliability Coefficients }\end{array}$ & Items \\
\hline F1 &, 796 &, 791 & 8 \\
F2 &, 770 &, 767 & 6
\end{tabular}




\begin{tabular}{cccc} 
F3 &, 763 &, 750 & 6 \\
F4 &, 774 &, 751 & 5 \\
F5 &, 757 &, 776 & 5 \\
\hline Total &, $\mathbf{8 3 7}$ & $\mathbf{8 3 2}$ & $\mathbf{3 0}$ \\
\hline
\end{tabular}

The Cronbach's Alpha and Spearman Brown reliability coefficients shown in Table 4 were calculated for all factors of the scale and values between .75 and .79 were found. When the Cronbach's Alpha coefficient is between .70 and .80 , on a scale aiming at comparing the groups this means that the scale is satisfactorily reliable (Bland \& Altman, 1997). In this situation Spearman Brown reliability coefficient is also acceptable (Büyüköztürk, 2014). In addition, the reliability coefficients calculated for all items of the scale are above .80 and satisfactory.

Table 5. Item Total Correlation Scores and Independent Samples T Test Results of The Lower $27 \%$ and the Upper $27 \%$ Groups

\begin{tabular}{|c|c|c|c|}
\hline Factors & Item Number & Item Total Correlation $^{1}$ & $\begin{array}{c}\mathrm{t} \\
(\text { Lower \%27-Upper \%27) } \\
\end{array}$ \\
\hline \multirow{8}{*}{$\vec{I}$} & 13 &, 530 & $-14,273$ \\
\hline & 14 &, 571 & $-14,095$ \\
\hline & 18 & ,467 & $-10,368$ \\
\hline & 19 & ,456 & $-11,900$ \\
\hline & 25 &, 544 & $-12,947$ \\
\hline & 27 & , 485 & $-11,814$ \\
\hline & 30 &, 502 & $-11,433$ \\
\hline & 32 & ,494 & $-13,282$ \\
\hline \multirow{6}{*}{$\underset{\Sigma}{N}$} & 1 & ,438 & $-12,945$ \\
\hline & 2 & 681 & $-14,445$ \\
\hline & 5 & 632, & $-16,571$ \\
\hline & 23 & ,408 & $-11,535$ \\
\hline & 44 & ,468 & $-13,389$ \\
\hline & 46 &, 502 & $-12,186$ \\
\hline \multirow{6}{*}{$\mathscr{E}$} & 4 & ,351 & $-12,386$ \\
\hline & 21 & 345 & $-11,530$ \\
\hline & 28 & ,401 & $-13,233$ \\
\hline & 36 & ,430 & $-14,266$ \\
\hline & 37 & ,477 & $-16,780$ \\
\hline & 38 & ,318 & $-10,332$ \\
\hline \multirow{5}{*}{$\vec{I}$} & 11 & ,427 & $-16,064$ \\
\hline & 29 & ,385 & $-12,054$ \\
\hline & 40 & , 428 & $-15,983$ \\
\hline & 41 & 381 & $-12,663$ \\
\hline & 45 & , 430 & $-16,097$ \\
\hline \multirow{5}{*}{10} & 7 & ,305 & $-9,751$ \\
\hline & 9 & ,356 & $-10,460$ \\
\hline & 10 & ,381 & $-12,600$ \\
\hline & 15 & ,424 & $-12,524$ \\
\hline & 42 &, 376 & $-11,709$ \\
\hline
\end{tabular}

As shown in Table 5, the item total correlations of the items included in the scale ranged from .31 to .68. Also, the difference between the mean scores of the lower $27 \%$ and the upper $27 \%$ groups was significant ( $\mathrm{p}<.001)$. Significant difference between the mean scores of the lower $27 \%$ and the upper $27 \%$ and the items with a total score of .30 and above indicate that the scale is consistent and distinguishes the participants well (Büyüköztürk, 2014). 


\section{CONCLUSION, DISCUSSION AND SUGGESTIONS}

This study was conducted to develop a scale that will enable the evaluation of faculty of education programs with the perspectives of teacher candidates. In this context, the validity and reliability studies of the Teacher Training Curriculum Evaluation Scale (TTCES) were carried out. After Kaiser-MayerOlkin (KMO) and Bartlett Sphericity Tests, exploratory factor analysis was applied to determine the construct validity of the scale. The reliability of the scale was evaluated according to the results of "Cronbach's Alpha", "Spearman-Brown" reliability coefficients, Independent Samples T Test between the lower $27 \%$ and the upper $27 \%$ groups and Item Total Correlation scores. After these analyzes, the draft consisting of 47 items, became a valid and reliable 5-point Likert type scale with 5 factors and 30items explaining $43.2 \%$ of the total variance.

The factors included in the scale by taking the theoretical infrastructure into account are named and sorted as follows:

1. Items related to the qualifications of teaching profession,

2. Items related to the number of students and instructors,

3. Items related to the facilities of the faculty,

4. Items related to education, measurement and evaluation activities,

5. Items related to the deficiencies of curriculum and precautions to be taken.

Objective, content, education and evaluation elements could be considered as the main elements of the curriculum and the context, input, process and product dimensions are commonly used in curriculum evaluation processes especially in System/Decision-Oriented Approach and models (Alkin \& Woolley, 1969; Kellaghan \& Stufflebeam 2003; Demirel, 2012; Ertürk 2013). In this context, the factors related to the qualifications of the teaching profession, the number of students and instructors, and the facilities of the faculty include objective and content elements of the curriculum and context and input dimensions of curriculum evaluation processes. Moreover, the factors related to education, measurement and evaluation activities include the educational aspects of the curriculum, evaluation element (especially formative evaluation) of the curriculum and the items covering the process dimension of the curriculum evaluation. Finally, the factors related to the deficiencies of curriculum and precautions to be taken include the evaluation element (especially summative evaluation) of the curriculum and the items covering the product dimension of the program evaluation. All these themes indicate that the scale also covers the basis of its dimensions taken into consideration such as main elements of the curriculum and dimensions commonly used in curriculum evaluation processes. This shows that the developed scale is also sufficient in terms of content validity.

Consequently, after recoding the negative item scores of TTCES, it will be beneficial for the researchers to increase the data diversity in the student dimension who want to evaluate the faculty education programs. In addition, high total scores obtained from the scale will indicate high curriculum qualifications.

The validity and reliability analysis by different researchers in different faculties of education may increase the quality of the prepared scale. Curriculum evaluation processes might become more efficient and realistic by increasing the number of such studies, which will enable the inclusion of students who are adults especially in higher education institutions. Moreover, similar scale development studies can be conducted to evaluate the programs of different faculties. 


\section{REFERENCES}

Akdoğdu, E., \& Ușun, S. (2017). Sınıf öğretmenliği lisans programının öğretmen adaylarının görüşleri doğrultusunda bağlam, girdi, süreç ve ürün (CIPP) modeli ile değerlendirilmesi. (In Turkish). Ilköğretim Online, 16(2), 826-847.

Alkin, M. C., \& Woolley, D. C. (1969, 8-11 October). A Model for Educational Evaluation. presented at PLEDGE Conference, San Dimas, 1-11.

Aslan, M., Soyalp, H., Karahan, O., \& Altuntaş, M. (2016). Okul öncesi eğitim programı değerlendirme ölçeğinin geliştirilmesi. (In Turkish). Yüzüncü Yll Üniversitesi Eğitim Fakültesi Dergisi, 13(1), 657-683.

Aygören, F., \& Er, K. O. (2018). Eğitim programlarını değerlendirmeye ait sinıflamalar. (In Turkish). Turkish Studies Eğitim Bilimleri Dergisi, 13(11), 269-296.

Baş, G. (2016). Eğitim programlarını değerlendirme ölçeği: Geçerlik ve güvenirlik çalışması. (In Turkish). Turkish Journal of Educational Studies, 3(1): 53-80.

Bland, J. M., \& Altman, D. G. (1997). Cronbach's alpha. BMJ: British Medical Journal, 314(7080), 570572.

Budak, M. (2011). 2005 ilköğretim matematik dersi 6-8. Sinıflar öğretim programına iliş̧kin öğretmen görüsleri. (In Turkish). Unpublished Master thesis. Erzincan University, Department of Mathematics Education, Erzincan. Retrieved from https://tez.yok.gov.tr/UlusalTezMerkezi.

Büyüköztürk, Ş. (2002). Faktör analizi: Temel kavramlar ve ölçek geliştirmede kullanımı. (In Turkish). Kuram ve Uygulamada Eğitim Yönetimi, 32(32), 470-483.

Büyüköztürk, Ş. (2014). Sosyal bilimler için veri analizi el kitabı. (In Turkish). (Extended 3rd Edition). Ankara: Pegem Akademi Yayıncılık.

Çokluk, Ö., Şekercioğlu, G. \& Büyüköztürk, Ş. (2016). Sosyal bilimler için çok değişskenli istatistik SPSS ve lisrel uygulamaları. (In Turkish). ( $4^{\text {th }}$ Edition). Ankara: Pegem Yayıncılık.

Demirel, Ö. (2012). Eğitimde program geliştirme, kuramdan uygulamaya, (In Turkish). (18 ${ }^{\text {th }}$ Edition). Ankara: Pegem Akademi Yayınları.

Demirtaş, Z. (2017). Eğitimde program değerlendirme yaklaşımlarına genel bir bakış. (In Turkish). Sakarya University Journal of Education, 7(4), 756-768.

Dimitrov, D. M. (2012). Statistical methods for validation of assessment scale data in counseling and related fields. USA: John Wiley \& Sons.

Eisner, E. W. (2002). The arts and the creation of mind. Londra: Yale University Press.

Ertürk, S. (2013). Eğitimde "program” geliştirme (In Turkish). (6 ${ }^{\text {th }}$ Edition). Ankara: Edge Akademi Yayınları.

Fitzpatrick, J. L., Sanders, J. R., \& Worthen, B. R. (2011). Program evaluation: Alternative approaches and practical guidelines. ( $4^{\text {th }}$ Edition). New Jersey: Pearson Education Inc.

Garson, G. D. (2013). Validity and reliability. Asheboro, NC: Statistical Associates Publishers.

Kavgaoğlu, D. (2017). Çağrı merkezi mesleki yetkinlik gelişstirme eğitim programının değerlendirilmesi (In Turkish). Unpublished PhD thesis, Y1ldz Technical University, Department of Educational Sciences, İstanbul. Retrieved from https://tez.yok.gov.tr/UlusalTezMerkezi.

Kellaghan, T., \& Stufflebeam, D. L. (Eds.). (2003). International handbook of educational evaluation: part one: Perspectives. Kluwer Academic Publishers.

Metfessel, N. S., \& Michael, W. B. (1967). A paradigm involving multiple criterion measures for the evaluation of the effectiveness of school programs. Educational and Psychological Measurement, 27(4), 931-943. 
Ornstein, A. C. \& Hunkins, F. P. (2018). Curriculum: Foundations, principles, and issues. (2 ${ }^{\text {nd }}$ Edition). Edinburgh: Pearson Education Limited.

Öksüz, C. (2015). İlkokul matematik programını değerlendirme ölçeği. (In Turkish). Pamukkale Üniversitesi Ĕ̈itim Fakültesi Dergisi, 37(1), 21-33.

Patton, M. Q. (2015). Qualitative research and evaluation methods. (4 ${ }^{\text {th }}$ Edition). Thousand Oaks. Cal.: Sage.

Provus, M. M. (1969). The Discrepancy Evaluation Model: An Approach to Local Program Improvement and Development. 8 Ocak 2019 tarihinde https://eric.ed.gov/?id=ED030957 adresinden erişildi.

Stake, R. E. (1967). The countenance of educational evaluation. Department for Exceptional Children, Gifted Children Section.

Stufflebeam, D. L., Madaus, G. F., \& Kellaghan, T. (Eds.). (2006). Evaluation models: Viewpoints on educational and human services evaluation. ( $2^{\text {nd }}$ Edition). Berlin: Springer Science \& Business Media.

Stufflebeam, D. L., \& Coryn, C. L. S. (2014). Evaluation theory, models, and applications. (2 ${ }^{\text {nd }}$ Edition). San Francisco: Josey-Bass.

Tabachnick B. G., \& Fidell, L. S. (2013). Using multivariate statistics. $\left(6^{\text {th }}\right.$ Edition). Boston: Pearson Education Inc.

Thompson, B. (2004). Exploratory and confirmatory factor analysis: Understanding concepts and applications. USA: American Psychological Association.

Uşun, S. (2012). Eğitimde program değerlendirme: Süreçler yaklaşımlar ve modeller. (In Turkish). Ankara: Anı Yayıncılık.

Yüksel, İ., \& Sağlam, M. (2014). Eğitimde program değerlendirme. (In Turkish). (2 ${ }^{\text {nd }}$ Edition). Ankara: Pegem Akademi. 


\section{CURRICULUM EVALUATION RESEARCH EXAMINED DURING THE DEVELOPMENT OF THE SCALE}

Abat, E. Z. Ç. (2016). 9. sınıf matematik dersi ögretim programının bağlam, girdi, süreç, ürün değerlendirme modeline göre değerlendirilmesi. (In Turkish). Master thesis. Akdeniz Üniversitesi, Eğitim Bilimleri Anabilim Dal1, Antalya. Retrieved from https://tez.yok.gov.tr/UlusalTezMerkezi.

Aktaş, C. K. (2018). Aydın Adnan Menderes Üniversitesi Yabancı Diller Yüksek Okulu İngilizce hazırlı programının Bellon ve Handler modeline göre değerlendirilmesi: Bir durum çalı̧̧ması. (In Turkish). PhD thesis Aydın Adnan Menderes Üniversitesi, Eğitim Bilimleri Anabilim Dalı, Aydın. Retrieved from https://tez.yok.gov.tr/UlusalTezMerkezi.

Altındağ, A. (2017). Ortaokul 5. sinlf matematik dersi ögretim programının Stake'in uygunluk-olasılık modeline göre değerlendirilmesi. (In Turkish). $\mathrm{PhD}$ thesis. Hacettepe Üniversitesi, Eğitim Bilimleri Anabilim Dalı, Ankara. Retrieved from https://tez.yok.gov.tr/UlusalTezMerkezi.

Arseven, İ. (2009). Bağlam ve süreç boyutlarında bir hizmetiçi eğitim programının değerlendirilmesi. (In Turkish). $\mathrm{PhD}$ thesis. Hacettepe Üniversitesi, Eğitim Bilimleri Anabilim Dalı, Ankara. Retrieved from https://tez.yok.gov.tr/UlusalTezMerkezi.

Aslan, M., \& Çıkar, İ. (2017). 4. sınıf matematik öğretim programının Tyler'ın hedefe dayalı program değerlendirme modeline göre değerlendirilmesi. (In Turkish). Necatibey Eğitim Fakültesi Elektronik Fen ve Matematik Ĕ̈itimi Dergisi, 11(2), 172-196.

Aslan, M., \& Erden, R. Z. (2018). Evaluation of 5 th grade science curriculum. Necatibey Faculty Of Education Electronic Journal Of Science \& Mathematics Education, 12(2), 508-537.

Aydın, S., Şentürk, Ş., \& Duran, V. (2018). Okul öncesi programının stufflebeam bağlam, girdi, süreç ve ürün modeline göre değerlendirilmesi. (In Turkish). Electronic Turkish Studies, 13(27): 163-181.

Babacan, T. (2016). Dokuzuncu sınıf İngilizce dersi ögretim programının bütüncül eğitime göre değerlendirilmesi. (In Turkish). $\mathrm{PhD}$ thesis. Eskişehir Osmangazi Üniversitesi, Eğitim Bilimleri Anabilim Dalı, Eskişehir. Retrieved from https://tez.yok.gov.tr/UlusalTezMerkezi.

Başaran, S. T., \& Ulubey, Ö. (2018). 2013 okul öncesi eğitim programının değerlendirilmesi. (In Turkish). Ankara Üniversitesi Ĕ̈itim Bilimleri Fakültesi Dergisi, 51(2), 1-38.

Bayat, S. (2012). Stake'in uygunluk/olastlık modeline göre ilkokuma yazma programinın değerlendirilmesi. (In Turkish). PhD thesis. Abant İzzet Baysal Üniversitesi, Eğitim Bilimleri Anabilim Dal, Bolu. Retrieved from https://tez.yok.gov.tr/UlusalTezMerkezi.

Bayık, S. (2018). Saç bakımı ve güzellik hizmetleri ön lisans programının Metfessel-Michael modeline göre değerlendirilmesi. (In Turkish). Master thesis. Aydın Adnan Menderes Üniversitesi, Eğitim Bilimleri Anabilim Dalı, Aydın. Retrieved from https://tez.yok.gov.tr/UlusalTezMerkezi.

Caner, H. N. (2018). Öğretmenlik uygulaması dersinin bağlam, girdi, süreç, ürün modeline göre değerlendirilmesi: ingilizce ögretmenliği lisans programı örneği. (In Turkish). Master thesis. Akdeniz Üniversitesi, Eğitim Bilimleri Anabilim Dalı, Antalya. Retrieved from https://tez.yok.gov.tr/UlusalTezMerkezi.

Canoğlu, S. N. (2014). Türkçe ve matematik ögretim programlarının değer tabanl program değerlendirme modeline göre incelenmesi. (In Turkish). Master thesis. Kırıkkale Üniversitesi, Eğitim Bilimleri Anabilim Dalı, Kırıkkale. Retrieved from https://tez.yok.gov.tr/UlusalTezMerkezi.

Cansu, T. (2010). Anadolu üniversitesi ilkögretimde teknoloji uygulamaları e-sertifika programının ögrrenen görüşüne göre bağlam, girdi, süreç ve ürün (CIPP) modeli ile değerlendirilmesi. (In Turkish). Master thesis. Anadolu Üniversitesi, Uzaktan Eğitim Anabilim Dalı, Eskişehir. Retrieved from https://tez.yok.gov.tr/UlusalTezMerkezi. 
Çelik, K. (2018). Ortaöğretim İngilizce dersi öğretim programının (2014) Eisner modeline göre değerlendirilmesi. (In Turkish). Master thesis. Gazi Üniversitesi, Eğitim Bilimleri Anabilim Dalı, Ankara. Retrieved from https://tez.yok.gov.tr/UlusalTezMerkezi.

Dinçer, B. (2013). 7. sınıf İngilizce öğretim programının Stufflebeam'in Bağlam-Girdi-Süreç-Ürün (CIPP) modeline göre değerlendirilmesi. PhD thesis. Aydın Adnan Menderes Üniversitesi, Eğitim Bilimleri Anabilim Dal, Aydın. Retrieved from https://tez.yok.gov.tr/UlusalTezMerkezi.

İlhan, E. (2018). Üniversitelerin lisans programlarında uygulanan çekirdek programın değerlendirilmesi. (In Turkish). PhD thesis. Gazi Üniversitesi, Eğitim Bilimleri Anabilim Dalı, Ankara. Retrieved from https://tez.yok.gov.tr/UlusalTezMerkezi.

Kavgaoğlu, D. (2017). Çağrı merkezi mesleki yetkinlik gelişstirme eğitim programının değerlendirilmesi. (In Turkish). PhD thesis. Yıldız Teknik Üniversitesi, Eğitim Bilimleri Anabilim Dalı, İstanbul. Retrieved from https://tez.yok.gov.tr/UlusalTezMerkezi.

Kotluk, N., \& Yayla, A. (2016). Ortaöğretim 9. Sınıf Fizik Öğretim Programının Tyler'ın Hedefe Dayalı Değerlendirme Modeline Göre Değerlendirilmesi. (In Turkish). Abant İzzet Baysal Üniversitesi Eğitim Fakültesi Dergisi, 16(4), 1832-1852.

Kumral, O. (2010). Ĕ̌itsel eleştiri modeli ile eğitim fakültesi sınıf öğretmenliği öğretim programının değerlendirilmesi: Bir durum çalışmast. (In Turkish). PhD thesis. Aydın Adnan Menderes Üniversitesi, Eğitim Bilimleri Anabilim Dalı, Aydın. Retrieved from https://tez.yok.gov.tr/UlusalTezMerkezi.

Kurt, A. (2016). 4. sınıf İngilizce dersi öğretim programının bağlam, girdi, süreç, ürün modeline göre değerlendirilmesi. (In Turkish). Master thesis. Akdeniz Üniversitesi, Eğitim Bilimleri Anabilim Dalı, Antalya). Retrieved from https://tez.yok.gov.tr/UlusalTezMerkezi.

Kuzu, S. (2015). Öğretim ilke ve yöntemleri ders programının değerlendirilmesi. (In Turkish). $\mathrm{PhD}$ thesis. Gaziantep Üniversitesi, Eğitim Bilimleri Anabilim Dalı, Gaziantep. Retrieved from https://tez.yok.gov.tr/UlusalTezMerkezi.

Mutlu, G. (2018). Program evaluation study of the main course at a preparatory program: A case study. Turkish Online Journal Of Qualitative Inquiry, 9(3), 202-239.

Orhan, A. (2016). Uzaktan eğitimle yürütülen yabancı dil dersi öğretim programının bağlam, girdi, süreç ve ürün (CIPP) modeli ile değerlendirilmesi. (In Turkish). Master thesis. Düzce Üniversitesi, Eğitim Bilimleri Anabilim Dalı, Düzce. Retrieved from https://tez.yok.gov.tr/UlusalTezMerkezi.

Ödemiş, S. İ. (2018). Meslek yüksekokulu İngilizce ögrretim programının bağlam girdi süreç ürün (CIPP) modeli kullanılarak değerlendirilmesi. (In Turkish). $\mathrm{PhD}$ thesis. Eskişehir Osmangazi Üniversitesi, Eğitim Bilimleri Anabilim Dalı, Eskişehir. Retrieved from https://tez.yok.gov.tr/UlusalTezMerkezi.

Özdil, N. G. (2016). Sosyal bilimler lisesi programının değerlendirilmesi. (In Turkish). Master thesis. Gazi Üniversitesi, Eğitim Bilimleri Anabilim Dalı, Ankara. Retrieved from https://tez.yok.gov.tr/UlusalTezMerkezi.

Özüdoğru, F. (2016). İlkokul 2. sınıf İngilizce öğretim programının diller için Avrupa ortak başvuru metni doğrultusunda aydınlatıcı değerlendirme modeli ile değerlendirilmesi. (In Turkish). $\mathrm{PhD}$ thesis. Anadolu Üniversitesi, Eğitim Bilimleri Anabilim Dalı, Eskişehir. Retrieved from https://tez.yok.gov.tr/UlusalTezMerkezi.

Serçek, G. Ö. (2014). Önlisans turizm eğitim programının CIPP modeline göre değerlendirilmesi. (In Turkish). PhD thesis. Dicle Üniversitesi, Eğitim Bilimleri Anabilim Dalı, Diyarbakır. Retrieved from https://tez.yok.gov.tr/UlusalTezMerkezi.

Şeref, M., \& Gözütok, F. D. (2018). Bir program değerlendirme örneği: doğum eğitimi. (In Turkish). Ihlara Eğitim Araştırmaları Dergisi, 3(1), 64-77. 
Tekmen, B. (2012). Okul öncesi öğretmenliği programının akademisyenlerin bakış açısıyla değerlendirilmesi. (In Turkish). PhD thesis. Orta Doğu Teknik Üniversitesi, Eğitim Bilimleri Anabilim Dal, Ankara. Retrieved from https://tez.yok.gov.tr/UlusalTezMerkezi.

Tunç, F. (2010). Ankara Üniversitesi Hazırlık Okulu programının CIPP modeli ile değerlendirilmesi. (In Turkish). Master thesis. Orta Doğu Teknik Üniversitesi, Eğitim Bilimleri Anabilim Dalı, Ankara. Retrieved from https://tez.yok.gov.tr/UlusalTezMerkezi.

Yeşilyurt, E. (2010). Öğretmenlik uygulaması öğretim programının standart temelli ve ihtiyaca cevap verici modeller ışığında değerlendirilmesi. (In Turkish). PhD thesis. Furat Üniversitesi, Eğitim Bilimleri Anabilim Dalı, Elazığ. Retrieved from https://tez.yok.gov.tr/UlusalTezMerkezi.

Yurdakul, B., Uslu, Ö., Çakar, E., \& Yıldız, D. G. (2014). Web tabanlı içerik geliştirme mesleki gelişim programının değerlendirilmesi. (In Turkish). Educational Sciences: Theory Practice, 14(4), 14091437. 


\begin{tabular}{|c|c|c|c|c|c|c|}
\hline \multicolumn{2}{|r|}{ Öğretmen Eğitimi Programlarını Değerlendirme Ölçeği (ÖEPDÖ) } & 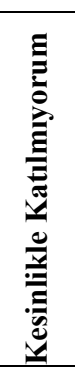 & 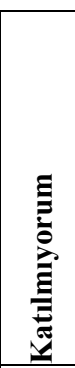 & 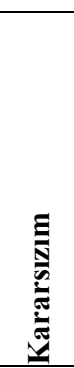 & 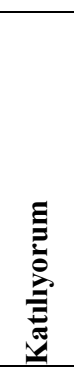 & 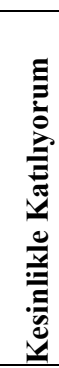 \\
\hline 1. & $\begin{array}{l}\text { Fakültemizde eğitim-öğretim faaliyetleri etkin yöntem ve tekniklerle } \\
\text { yürütülür. }\end{array}$ & (1) & $(2)$ & (3) & (4) & (5) \\
\hline 2. & $\begin{array}{l}\text { Fakültemizde dersler öğrenci ve öğretim elemanı arasında uyumlu bir } \\
\text { șekilde yürütülür. }\end{array}$ & (1) & $(2)$ & (3) & (4) & (5) \\
\hline 3. & Fakültemizde eğitim-öğretim faaliyetleri başarılı bir şekilde yürütülür. & (1) & (2) & (3) & (4) & (5) \\
\hline 4. & Fakültemizde dersler nitelikli öğretim elemanları tarafından yürütülür. & (1) & $(2)$ & (3) & (4) & (5) \\
\hline 5. & $\begin{array}{l}\text { Fakülttemizde öğrencilerin başarı durumu öğretim elemanları } \\
\text { tarafından önemsenir. }\end{array}$ & (1) & (2) & (3) & (4) & (5) \\
\hline 6. & $\begin{array}{l}\text { Fakültemizde ölçme ve değerlendirme faaliyetleri uygun ve adil bir } \\
\text { biçimde yürütülür. }\end{array}$ & (1) & $(2)$ & (3) & (4) & (5) \\
\hline 7. & $\begin{array}{l}\text { Fakültemizde öğrenciler eğitim-öğretimde gösterdikleri çabanın } \\
\text { karşıllğını alır. }\end{array}$ & (1) & (2) & (3) & (4) & (5) \\
\hline 8. & Fakültemizde öğrenciler gösterdikleri çaba oranında başarılıdır. & (1) & $(2)$ & (3) & (4) & $(5)$ \\
\hline \multicolumn{7}{|c|}{ F2. Öğretmenlik Mesleği Yeterliklerine İlişkin Maddeler } \\
\hline 9. & $\begin{array}{l}\text { Fakültemizden öğretmenlik mesleğini başarıyla yürütebilecek bireyler } \\
\text { mezun olur. }\end{array}$ & (1) & $(2)$ & (3) & (4) & (5) \\
\hline 10. & $\begin{array}{l}\text { Fakültemizden öğretmenlik için gereken mesleki değerlere sahip } \\
\text { bireyler mezun olur. }\end{array}$ & (1) & $(2)$ & (3) & (4) & (5) \\
\hline 11. & edilen öğrenciler, öğretmen olabilecek niteliktedir. & (1) & (2) & (3) & (4) & (5) \\
\hline 12. & men olma niyetiyle gelir. & (1) & $(2)$ & (3) & (4) & (5) \\
\hline 13. & Fakültemiz öğretmenlik mesleğinin öğrenileceği uygu & (1) & $(2)$ & (3) & (4) & (5) \\
\hline 14. & $\begin{array}{l}\text { Fakültemizde yürütülen dersler nitelikli öğretmen yetiştirme amacına } \\
\text { hizmet eder. }\end{array}$ & (1) & (2) & (3) & (4) & (5) \\
\hline \multicolumn{7}{|c|}{ F3. Fakültenin Sahip Olduğu İmkanlara İlişkin Maddeler } \\
\hline 15. & Fakültemizin fiziki imkanları eğitim-öğretim için yeterlidir. & (1) & (2) & (3) & (4) & (5) \\
\hline 16. & Fakül & (1) & $(2)$ & (3) & (4) & (5) \\
\hline 17. & Fakültemiz eğitim-öğretim için yeterli teknolojik altyap & (1) & $(2)$ & (3) & (4) & (5) \\
\hline 18. & $\begin{array}{l}\text { Fakültemizde ders konularını tamamlamak adına planlanan süreler } \\
\text { uygundur. }\end{array}$ & (1) & (2) & (3) & (4) & (5) \\
\hline 19. & $\begin{array}{l}\text { Fakültemizde ders konularını planlanan sürelerde tamamlamak } \\
\text { güçtür. }\end{array}$ & (1) & (2) & (3) & (4) & (5) \\
\hline 20. & $\begin{array}{l}\text { Fakültemizde öğretmenlik mesleği için verilen teorik bilgiler } \\
\text { sınırlıdır. }\end{array}$ & (1) & $(2)$ & (3) & (4) & (5) \\
\hline \multicolumn{7}{|c|}{ F4. Öğrenci ve Öğretim Elemanı Sayısına İlişkin Maddeler } \\
\hline 21. & Fakültemize ihtiyaçtan fazla öğrenci kabul edilir. & (1) & $(2)$ & (3) & (4) & $(5)$ \\
\hline 22. & Fakültemizin öğrenci kontenjanı ihtiyaçlara göre belirlenir. & (1) & $(2)$ & (3) & (4) & (5) \\
\hline 23. & Fakültemizde sınıflar gereğinden fazla kalabalıktır. & (1) & (2) & (3) & (4) & (5) \\
\hline 24. & Fakültemizde bölümlere göre öğrenci dağılımı orantısızdır. & (1) & $(2)$ & (3) & (4) & (5) \\
\hline 25. & $\begin{array}{l}\text { Fakültemizde eğitim-öğretimi yürütecek yeterli sayıda öğretim } \\
\text { elemanı vardır. }\end{array}$ & (1) & (2) & (3) & (4) & (5) \\
\hline
\end{tabular}




\begin{tabular}{|c|c|c|c|c|c|c|}
\hline \multicolumn{2}{|r|}{$\begin{array}{l}\text { F5. Eğitim Fakültesi Programlarının Aksaklıkları ve Alınması Gereken } \\
\text { Önlemlere İlişkin Maddeler }\end{array}$} & 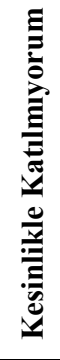 & 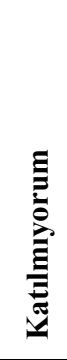 & 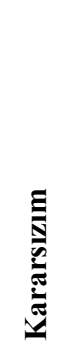 & 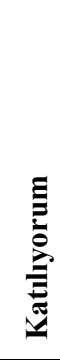 & \\
\hline 26. & $\begin{array}{l}\text { Fakültemizde öğretilen bazı bilgiler mesleki eğitim adına } \\
\text { gereksizdir. }\end{array}$ & (1) & (2) & (3) & (4) & (5) \\
\hline 27. & $\begin{array}{l}\text { Fakültemizde eğitim-öğretim faaliyetleri öğrencilerde bazen } \\
\text { istenmeyen özelliklerin olușmasına da sebep olur. }\end{array}$ & (1) & (2) & (3) & (4) & (5) \\
\hline 28. & $\begin{array}{l}\text { Fakültemizde uygulanan programlarda çeşitli geliştirme ve } \\
\text { iyileştirmeler yapılmalıdır. }\end{array}$ & (1) & (2) & (3) & (4) & (5) \\
\hline 29. & $\begin{array}{l}\text { Fakültemizin sahip olduğu imkanlar ile eğitim-öğretim daha iyi hale } \\
\text { getirilebilir. }\end{array}$ & (1) & (2) & (3) & (4) & (5) \\
\hline 30. & $\begin{array}{l}\text { Fakültemizde uygulanan programlar terk edilip yerine daha iyi } \\
\text { programlar hazırlanmalıdır. }\end{array}$ & (1) & (2) & (3) & (4) & (5) \\
\hline
\end{tabular}

Items written in bold are negative expressions. 